Note

\title{
ORGANIC CARBON DETERMINATION IN HISTOSOLS AND SOIL HORIZONS WITH HIGH ORGANIC MATTER CONTENT FROM BRAZIL
}

\author{
Marcos Gervasio Pereira ${ }^{1 *}$; Gustavo Souza Valladares ${ }^{2}$; Lúcia Helena Cunha dos Anjos ${ }^{1}$; \\ Vinícius de Melo Benites ${ }^{3}$; Ademar Espíndula Jr. ${ }^{1}$; Adierson Gilvani Ebeling ${ }^{1}$ \\ ${ }^{1}$ UFRRJ - Depto. de Solos, BR 465, km 7 - 23900-000 - Seropédica, RJ - Brasil. \\ ${ }^{2}$ Embrapa Monitoramento por Satélite, Av. Dr. Júlio Soares de Arruda, 803 - 13088-300 - Campinas, SP - \\ Brasil. \\ ${ }^{3}$ Embrapa Solos, R. Jardim Botânico, 1024 - 22460-000 - Rio de Janeiro, RJ - Brasil. \\ *Corresponding author <gervasio@ufrrj.br>
}

\begin{abstract}
Soil taxonomy systems distinguish mineral soils from organic soils based on the amount of soil organic carbon. Procedures adopted in soil surveys for organic carbon measurement are therefore of major importance to classify the soils, and to correlate their properties with data from other studies. To evaluate different methods for measuring organic carbon and organic matter content in Histosols and soils with histic horizons, from different regions of Brazil, 53 soil samples were comparatively analyzed by the methods of Walkley \& Black (modified), Embrapa, Yeomans \& Bremner, modified Yeomans \& Bremner, muffle furnace, and CHN. The modified Walkley \& Black (C-W \& B md) and the combustion of organic matter in the muffle furnace (OM-Muffle) were the most suitable for the samples with high organic carbon content. Based on regression analysis data, the OM-muffle may be estimated from $\mathrm{C}-\mathrm{W} \& \mathrm{~B}$ md by applying a factor that ranges from 2.00 to 2.19 with $95 \%$ of probability. The factor 2.10 , the average value, is suggested to convert results obtained by these methods.

Key words: Walkley \& Black, Yeomans \& Bremner, soil taxonomy, soil organic matter methods, soil chemical analysis
\end{abstract}

\section{DETERMINAÇÃO DO CARBONO ORGÂNICO EM ORGANOSSOLOS E SOLOS COM HORIZONTES COM ELEVADO CONTEÚDO DE MATÉRIA ORGÂNICA}

\begin{abstract}
RESUMO: Sistemas taxonômicos distinguem horizontes e/ou camadas minerais das orgânicas baseandose na quantidade de carbono orgânico. Assim, o procedimento adotado em pesquisas para a quantificação do conteúdo de carbono orgânico é de grande importância para a classificação das terras e correlacionar as suas propriedades com dados de outros estudos. Com o objetivo de avaliar os diferentes métodos para medir o conteúdo de carbono orgânico e de matéria orgânica em Organossolo e solos com elevados teores de matéria orgânica, de diferentes regiões do Brasil, cinqüenta e três amostras de terra foram comparativamente analisadas pelos métodos de Walkley \& Black (modificado), Embrapa, Yeomans \& Bremner, Yeomans \& Bremner modificado, forno mufla, e CHN. O método Walkley \& Black modificado (C-W \& B md) e a combustão de matéria orgânica no forno mufla (MO-Mufla) revelaram-se mais satisfatórios para as amostras com elevado conteúdo de carbono orgânico. Com base em dados de análise de regressão, os teores de matéria orgânica determinados pela mufla podem ser calculados a partir dos dados de C-W \& B md aplicando-se um fator que varia de 2,00 a 2,19 com 95\% de probabilidade. O fator 2,10 , valor médio, é sugerido para a conversão dos resultados obtidos por estes métodos.

Palavras-chave: Walkley \& Black, Yeomans \& Bremner, classificação de solo, métodos para matéria orgânica do solo, análises químicas de solo
\end{abstract}

\section{INTRODUCTION}

Soil taxonomy systems (FAO, 1998; Embrapa, 1999; USDA, 1999) differentiate mineral and organic soils. To do so, it is necessary distinguishing mineral soil material from organic soil material, the main criterion being the amount of soil organic carbon. Also, the central concept of Histosols is that of soils forming in organic soil materials. Values of organic carbon in the National Soil Survey Laboratory (NSSL) data- 
base (USDA, 1996) have been determined mostly by wet digestion (Walkley \& Black, 1934; Walkley, 1935). Because of environmental concerns, that procedure is no longer in use. The method currently recommended by USDA (Soil Taxonomy, USDA, 1999; USDA, 1996) is based upon dry combustion (muffle furnace), and measures the percent of total carbon. The content of organic carbon is determined by subtracting the amount of carbon contributed by carbonates from total carbon data.

Brazilian soil surveys regularly adopt the wet digestion to measure soil organic carbon as a reference method for all soil classes (EMBRAPA, 1997). The recently published Brazilian Soil System of Classification - SiBCS (EMBRAPA, 1999) recommends the dry combustion procedure to measure soil organic matter in Histosols. To be able to recover data from previous soil surveys, a comparison between procedures to measure organic carbon and organic matter in Histosols (Organossolos) and soils with histic horizons is needed. Principles involved in these methods may be summarized as follows: a) wet digestion through oxidizing agents, such as the dichromate solution; and b) dry combustion in a muffle furnace or automatic equipment, such as the CHN elements analyzer, both measuring total carbon content.

The aim of this study was to evaluate different methods of organic carbon and organic matter determination in Histosols and soils with histic horizons, in the aim to contribute to an adequate characterization of these soils in the Brazilian Soil Classification System, additionally allowing the conversion of data obtained though one method to another. The comparison was made between the methods Walkley \& Black modified, Embrapa, Yeomans \& Bremner, modified Yeomans \& Bremner, muffle furnace, and CHN.

\section{MATERIAL AND METHODS}

For comparison of methods, 53 samples of $\mathrm{O}$ or $\mathrm{H}$ horizons were taken from soil profiles from different Brazilian states (Table 1). The soils were characterized through routine chemical and physical analysis (EMBRAPA, 1997; EMBRAPA, 1999) and analyzed for organic carbon and organic matter contents by the following methods:

Modified Walkley \& Black (C-W \& B md) - the procedure is a modification of the Walkley \& Black (1934) and Walkley $(1935 ; 1946)$ methods, according to Tedesco et al. (1995), described ahead. After weighing a soil sample containing an estimated amount from 10 to $25 \mathrm{mg}$ of $\mathrm{C}$ (corresponding to 0.1 to $0.3 \mathrm{~g}$ of soil), $10 \mathrm{~mL}$ of $\mathrm{K}_{2} \mathrm{Cr}_{2} \mathrm{O}_{7} 0.2 \mathrm{~mol} \mathrm{~L}^{-1}$ and $20 \mathrm{~mL}$ of concen- trated $\mathrm{H}_{2} \mathrm{SO}_{4}$ were added. The material was heated in a plate and homogenized carefully until reaching the temperature of $150^{\circ} \mathrm{C}$. After that, the material was removed from the plate, cooled to room temperature, and left to rest for 40 minutes. Later, $50 \mathrm{~mL}$ of distilled water was added and the sample shaken, then transferred the content into a $100 \mathrm{~mL}$ graduated flask and adjusted the volume, left to rest for 10-15 minutes, and then filtrated. The amount of $1 \mathrm{~mL}$ of concentrated phosphoric acid was added to the filtrate, and the extract was titrated with $0.25 \mathrm{~mol} \mathrm{~L}^{-1}$ of ammoniac ferrous sulfate solution, using diphenylamine $0.5 \%$ as indicator. The carbon content was calculated using the formula: $\% \mathrm{C}=\left[\left(\mathrm{mmol}_{\mathrm{c}} \mathrm{L}^{-1} \mathrm{Cr}_{2} \mathrm{O}_{7}^{2-}-\mathrm{mmol}_{\mathrm{c}} \mathrm{Fe}^{2+}\right) \times 0.3\right]$ / mass of sample $(\mathrm{g})$. A previous modification of the procedure (Allison, 1965) uses the factor 1.12 in the formula, which presumes the organic carbon partial oxidation, when an external heat source is not used. In this study, this factor was not considered.

Embrapa (C-Embrapa) - The procedure consisted of weighing $0.5 \mathrm{~g}$ of triturated soil (due to high organic matter contents, between 0.05 and $0.1 \mathrm{~g}$ of soil were weighted), placing the sample into a $250 \mathrm{~mL}$ Erlenmeyer flask, and adding $10 \mathrm{~mL}$ of potassium dichromate solution at $0.067 \mathrm{~mol} \mathrm{~L}^{-1}$. Also, a blank test with 10 $\mathrm{mL}$ of potassium dichromate solution was included, and the volume consumed recorded. A tube with distilled water was used as a condenser. The material was heated in an electric plate up to slight boiling point and kept for 5 minutes. After cooling, $80 \mathrm{~mL}$ of distilled water, plus $2 \mathrm{~mL}$ of orthophosphoric acid and 3 drops of diphenylamine were added. The sample was titrated with ammoniac ferrous sulfate $0.05 \mathrm{~mol} \mathrm{~L}^{-1}$, turning color from blue to green (EMBRAPA, 1997). The organic carbon content was then calculated by the formula:

$\mathrm{C}\left(\mathrm{g} \mathrm{kg}^{-1}\right)=[40$ - (titrating volume $\left.\mathrm{x} \mathrm{f})\right] \mathrm{x} 0.6$; $\mathrm{f}$ is a factor for the blank test.

Yeomans \& Bremner (C-Y \& B) - The soil was previously sieved, mesh lower than 100 , and the weighed sample, estimated to contain no more than $8 \mathrm{mg}$ of organic carbon (usually between 100 and $500 \mathrm{mg}$ of soil), was placed into a digestion tube $(100 \mathrm{~mL})$, and added of $5 \mathrm{~mL}$ of $\mathrm{K}_{2} \mathrm{Cr}_{2} \mathrm{O}_{7} 0.1667 \mathrm{~mol} \mathrm{~L}^{-1}$ and $7.5 \mathrm{~mL}$ of concentrated sulfuric acid. The tube was placed into a preheated digestion block at $170^{\circ} \mathrm{C}$ for 30 minutes. The tube was removed from the block and cooled for 15 minutes. The content was transferred into a Becker flask and the volume equaled to $50 \mathrm{~mL}$. The sample was cooled to room temperature, and $0.3 \mathrm{~mL}$ of the $\mathrm{N}$ phenylanthranilic acid-based indicator and sodium car- 
Table 1 - Localization, classification ${ }^{\S}$ and altitude of soil profiles.

\begin{tabular}{|c|c|c|c|c|c|}
\hline \multirow{2}{*}{$\begin{array}{l}\text { State, } \\
\text { Profile \# }\end{array}$} & \multirow{2}{*}{ Country } & \multirow{2}{*}{ Position } & \multicolumn{2}{|l|}{ Classification } & \multirow{2}{*}{ Altitude } \\
\hline & & & $\mathrm{SiBCS}$ & Soil Taxonomy & \\
\hline & & & & & $\mathrm{m}$ \\
\hline AL-1 & Jequiá da Praia & $10^{\circ} 1^{\prime} \mathrm{S} \quad 36^{\circ} 2^{\prime} \mathrm{W}$ & Organossolo Tiomórfico Fíbrico térrico & Terric Sulfihemists & 3 \\
\hline AL-2 & Coruripe & $10^{\circ} 7^{\prime} \mathrm{S} \quad 36^{\circ} 12^{\prime} \mathrm{W}$ & Organossolo Tiomórfico Hêmico típico & Typic Sulfohemists & 5 \\
\hline BA-2 & Ituberá & $13^{\circ} 42^{\prime} \mathrm{S} 38^{\circ} 59^{\prime} \mathrm{W}$ & Organossolo Tiomórfico Hêmico térrico & Typic Sulfohemists & 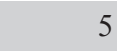 \\
\hline BA-3 & Arraial D'Ajuda & $16^{\circ} 27^{\prime} \mathrm{S} 39^{\circ} 6^{\prime} \mathrm{W}$ & Organossolo Tiomórfico Hêmico típico & Typic Sulfohemists & 7 \\
\hline DF -1 & Guará II & $15^{\circ} 48^{\prime} \mathrm{S} 48^{\circ} 1^{\prime} \mathrm{W}$ & Organossolo Mésico Sáprico típico & Typic Haplosaprists & 800 \\
\hline ES-1 & Mimoso do Sul & $21^{\circ} 17^{\prime} \mathrm{S} 41^{\circ} 12^{\prime} \mathrm{W}$ & Organossolo Mésico Hêmico típico & Hydric Haplohemists & 15 \\
\hline MG-1 & Juiz de Fora & $21^{\circ} 46^{\prime} \mathrm{S} 43^{\circ} 29^{\prime} \mathrm{W}$ & Organossolo Mésico Hêmico típico & $\begin{array}{l}\text { Fluvaquentic } \\
\text { Haplohemists }\end{array}$ & 874 \\
\hline MG-2 & Coronel Pacheco & $21^{\circ} 35^{\prime} \mathrm{S} 43^{\circ} 17^{\prime} \mathrm{W}$ & Organossolo Mésico Hêmico térrico & Hydric Haplohemists & 432 \\
\hline MS-2 & Porto Morumbi & $23^{\circ} 49^{\prime} \mathrm{S} 54^{\circ} 5^{\prime} \mathrm{W}$ & Organossolo Tiomórfico Sáprico térrico & Terric Haplosaprists & 280 \\
\hline PR-2 & Tijucas do Sul & $25^{\circ} 53^{\prime} \mathrm{S} 49^{\circ} 8^{\prime} \mathrm{W}$ & Organossolo Mésico Sáprico típico & Typic Haplosaprists & 850 \\
\hline PR-3 & Serra da Baitaca & $25^{\circ} 30^{\prime} \mathrm{S} 49^{\circ} 17^{\prime} \mathrm{W}$ & Neossolo Litólico Hístico típico & Lithic Udifolists & 1330 \\
\hline RJ-1 & $\begin{array}{l}\text { Parque Nacional } \\
\text { Itatiaia }\end{array}$ & $22^{\circ} 22^{\prime} \mathrm{S} 44^{\circ} 48^{\prime} \mathrm{W}$ & Cambissolo Húmico Distrófico típico & $\begin{array}{l}\text { Humic Pachic } \\
\text { Dystrudepts }\end{array}$ & 1700 \\
\hline RJ-3 & $\begin{array}{l}\text { São José da Boa } \\
\text { Morte }\end{array}$ & $22^{\circ} 34^{\prime} \mathrm{S} 42^{\circ} 42^{\prime} \mathrm{W}$ & Organossolo Háplico Hêmico térrico & Hydric Haplohemists & 40 \\
\hline RJ-4 & Nova Friburgo & $22^{\circ} 18^{\prime} \mathrm{S} 42^{\circ} 31^{\prime} \mathrm{W}$ & Organossolo Mésico Sáprico térrico & $\begin{array}{l}\text { Humaqueptic } \\
\text { Endoaquents }\end{array}$ & 800 \\
\hline RS-3 & Cambará do Sul & $29^{\circ} 7^{\prime} \mathrm{S} \quad 50^{\circ} 11^{\prime} \mathrm{W}$ & Organossolo Mésico Sáprico térrico & Terric Haplosaprists & 890 \\
\hline $\mathrm{RS}-4$ & Viamão & $30^{\circ} 10^{\prime} \mathrm{S} 50^{\circ} 49^{\prime} \mathrm{W}$ & Organossolo Tiomórfico Sáprico típico & Typic Sulfosaprists & 20 \\
\hline RS-5 & Viamão & $30^{\circ} 10^{\prime} \mathrm{S} 50^{\circ} 53^{\prime} \mathrm{W}$ & Organossolo Tiomórfico Sáprico típico & Typic Sulfosaprists & 20 \\
\hline $\mathrm{SC}-2$ & $\begin{array}{l}\text { Governador Celso } \\
\text { Portela }\end{array}$ & $27^{\circ} 21^{\prime} \mathrm{S} 48^{\circ} 37^{\prime} \mathrm{W}$ & Organossolo Tiomórfico Hêmico típico & Typic Sulfohemists & 10 \\
\hline SP-1 & Taubaté & $23^{\circ} 4^{\prime} \mathrm{S} \quad 45^{\circ} 33^{\prime} \mathrm{W}$ & Organossolo Mésico Sáprico térrico & Terric Haplosaprists & 500 \\
\hline
\end{tabular}

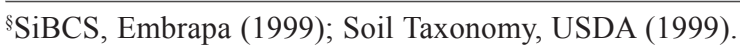

Brazilian States: AL, Alagoas; BA, Bahia; DF, Distrito Federal, Brasília; ES, Espírito Santo; MG, Minas Gerais; MS, Mato Grosso do Sul; PR, Paraná; RJ, Rio de Janeiro; RS, Rio Grande do Sul; SC, Santa Catarina; SP, São Paulo.

bonate were added. The titration was performed with ammoniac ferrous sulfate solution at $0.05 \mathrm{~mol} \mathrm{~L}^{-1}$. At the turning point, the color quickly turns from violet to green. For each series of samples, at least two blank proofs, with $5 \mathrm{~mL}$ of $\mathrm{K}_{2} \mathrm{Cr}_{2} \mathrm{O}_{7} 0.1667 \mathrm{~mol} \mathrm{~L}^{-1}$ and $7.5 \mathrm{~mL}$ of concentrated sulfuric acid, were placed in the series, one tube was heated and the other not (Yeomans \& Bremner, 1988). The organic carbon content was calculated similarly to the Walkley \& Black method.

Modified Yeomans \& Bremner (C-Y \& B md) - In this method there is a replacement of the acid-based $\mathrm{N}$-phenylanthranilic indicator and the sodium carbonate by $0.3 \mathrm{~mL}$ of diphenylamine at $0.5 \%$ and $1.0 \mathrm{~mL}$ of $\mathrm{H}_{3} \mathrm{PO}_{4}$. This modification was studied to adapt the Yeomans \& Bremner method to laboratory routine analysis conditions, aiming availability of reagents.
Muffle furnace (OM-Muffle) - A weighed amount of oven-dried soil sample $\left(105^{\circ} \mathrm{C} ; 24 \mathrm{~h}\right)$ was placed in a high-form porcelain crucible and set in a muffle furnace $\left( \pm 5^{\circ} \mathrm{C}\right.$ precision) for combustion at $600^{\circ} \mathrm{C}$ for 6 hours (Goldin, 1987). The organic matter content was determined through the mass difference in relation to the original soil sample.

C-CHN - carbon content was determined by dry combustion in an elementary Perkin Elmer 2400 CHNS analyzer, from $5.0 \pm 0.1 \mathrm{mg}$ soil samples.

All the analyses were performed in duplicate. The statistical method to compare the organic carbon contents obtained through different methods was the linear regression $\left(\mathrm{Y}=\mathrm{b}_{0}+\mathrm{b}_{1} \mathrm{X}\right)$, as suggested by Miller $\&$ Miller (1993). The null hypotheses were that the declivity $\left(b_{1}\right)$ would not be different from one (1), and that the intercept $\left(b_{0}\right)$ would not be different from zero 
(0). Such hypotheses were tested by means of the confidence limits calculation at $95 \%$ for both coefficients. The results were also submitted to analysis of variance ( $\mathrm{F}$ test), and correlation using the statistical analysis tools in Microsoft Excel 97 software.

\section{RESULTS AND DISCUSSION}

Results (Tables 2 and 3, and Figure 1) show that soil organic carbon and soil organic matter data
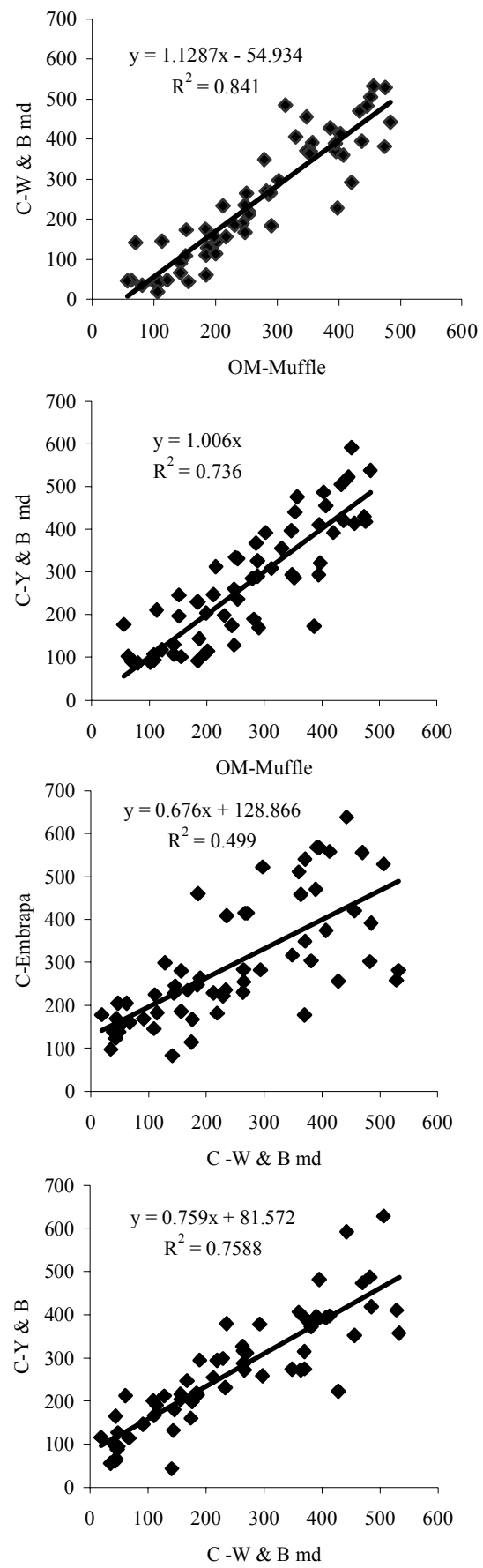

obtained from different methods are comparable. Reference materials were not used to test accuracy of the methods. The normal range of values of organic carbon or organic matter in Histosols is per se an unknown subject, since informations in Brazil regarding these soils are scarce.

The organic carbon and organic matter contents, and the factor that expresses the ratio between $\mathrm{C}$ content obtained in a given method and total carbon content (measured by the C-CHN method) are pre-
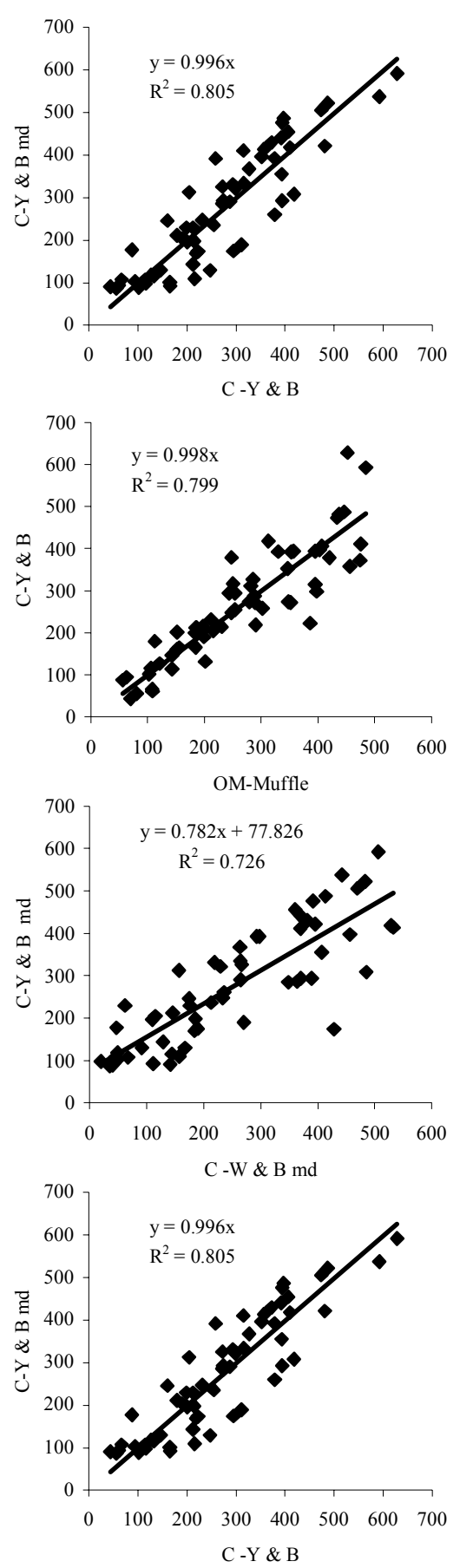

Figure 1 - Dispersion diagrams relating methods for carbon and organic matter $\left(\mathrm{g} \mathrm{kg}^{-1}\right)$ determination in Brazilian Histosols and soils with histic horizon. 
Table 2 - Carbon and organic matter of soil horizons according to different methods ${ }^{\S}$, and $\mathrm{C}$ factors (f-) related to total C (C-CHN).

\begin{tabular}{|c|c|c|c|c|c|c|c|c|c|c|}
\hline Profile & Horizon & $\mathrm{C}-\mathrm{CHN}$ & C-Emb. & f-Emb & OM-Muffle & f-muffle & $\mathrm{C}-\mathrm{W} \& \mathrm{~B}$ md & $f-W \& B$ & $C-Y \& B$ & $f-Y B$ \\
\hline & & 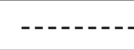 & . & - & . & g kg & - & $-\ldots-$ & $\ldots$ & $\ldots-\ldots$ \\
\hline \multirow{2}{*}{ AL-1 } & Hip 1 & 358 & 237 & 0.66 & 760 & 2.12 & 204 & 0.57 & 322 & 0.90 \\
\hline & Hip2 & 110 & 61 & 0.55 & 161 & 1.45 & 130 & 1.18 & 211 & 1.92 \\
\hline \multirow[t]{4}{*}{ AL-2 } & Hepj & 306 & 192 & 0.63 & 531 & 1.74 & 265 & 0.87 & 392 & 1.28 \\
\hline & Hej1 & 508 & 402 & 0.79 & 916 & 1.80 & 452 & 0.89 & 592 & 1.16 \\
\hline & Hej2 & 455 & 239 & 0.52 & 873 & 1.92 & 382 & 0.84 & 174 & 0.38 \\
\hline & Hij & 121 & 112 & 0.93 & 290 & 2.40 & 140 & 1.16 & 110 & 0.91 \\
\hline \multirow[t]{3}{*}{ BA-2 } & Haj & 525 & 369 & 0.70 & 909 & 1.73 & 431 & 0.82 & 522 & 0.99 \\
\hline & Hej1 & 529 & 232 & 0.44 & 963 & 1.82 & 341 & 0.64 & 430 & 0.81 \\
\hline & Hej2 & 370 & 192 & 0.52 & 740 & 2.00 & 262 & 0.71 & 393 & 1.06 \\
\hline \multirow[t]{3}{*}{ BA-3 } & Hepj1 & 388 & 322 & 0.83 & 807 & 2.08 & 369 & 0.95 & 487 & 1.26 \\
\hline & Hepj2 & 555 & 207 & 0.37 & 939 & 1.69 & 472 & 0.85 & 418 & 0.75 \\
\hline & Hej & 508 & 219 & 0.43 & 929 & 1.83 & 476 & 0.94 & 414 & 0.81 \\
\hline \multirow[t]{3}{*}{ DF-1 } & Нар & 102 & 89 & 0.87 & 187 & 1.84 & 97 & 0.96 & 196 & 1.93 \\
\hline & Ha 1 & 132 & 117 & 0.88 & 265 & 2.00 & 157 & 1.19 & 230 & 1.73 \\
\hline & $\mathrm{Ha} 2$ & 197 & 159 & 0.81 & 370 & 1.88 & 190 & 0.97 & 236 & 1.20 \\
\hline \multirow[t]{3}{*}{ ES-1 } & Hap 1 & 180 & 130 & 0.72 & 464 & 2.58 & 164 & 0.91 & 170 & 0.94 \\
\hline & Нар2 & 158 & 114 & 0.72 & 366 & 2.32 & 149 & 0.95 & 129 & 0.82 \\
\hline & $\mathrm{He}$ & 228 & 164 & 0.72 & 325 & 1.43 & 208 & 0.91 & 247 & 1.09 \\
\hline \multirow[t]{3}{*}{ MG-1 } & $\mathrm{He}$ & 279 & 218 & 0.78 & 615 & 2.21 & 324 & 1.16 & 286 & 1.03 \\
\hline & $\mathrm{Ha}$ & 214 & 142 & 0.66 & 412 & 1.93 & 210 & 0.98 & 260 & 1.22 \\
\hline & $2 \mathrm{He}$ & 367 & 215 & 0.59 & 672 & 1.83 & 322 & 0.88 & 455 & 1.24 \\
\hline \multirow[t]{2}{*}{ MG-2 } & $\mathrm{He} 1$ & 115 & 102 & 0.89 & 209 & 1.82 & 105 & 0.92 & 246 & 2.14 \\
\hline & $\mathrm{He} 2$ & 206 & 151 & 0.73 & 407 & 1.97 & 236 & 1.14 & 334 & 1.62 \\
\hline \multirow[t]{2}{*}{ MS-2 } & $\mathrm{He}$ & 121 & 98 & 0.81 & 291 & 2.40 & 103 & 0.85 & 204 & 1.68 \\
\hline & $2 \mathrm{Ha}$ & 189 & 139 & 0.74 & 337 & 1.78 & 165 & 0.87 & 198 & 1.05 \\
\hline \multirow[t]{3}{*}{ PR-2 } & Hap 1 & 144 & 122 & 0.85 & 279 & 1.93 & 99 & 0.69 & 92 & 0.64 \\
\hline & Hap2 & 193 & 160 & 0.83 & 376 & 1.95 & 169 & 0.88 & 175 & 0.91 \\
\hline & Hap3 & 270 & 190 & 0.70 & 485 & 1.80 & 238 & 0.88 & 326 & 1.21 \\
\hline PR-3 & $\mathrm{Oi}$ & 419 & 345 & 0.82 & 806 & 1.92 & 330 & 0.79 & 411 & 0.98 \\
\hline \multirow{3}{*}{ RJ-1 } & A1 & 64 & 61 & 0.96 & 144 & 2.26 & 40 & 0.64 & 107 & 1.69 \\
\hline & A2 & 38 & 31 & 0.83 & 93 & 2.46 & 31 & 0.83 & 87 & 2.28 \\
\hline & $\mathrm{Bi}$ & 50 & 42 & 0.85 & 130 & 2.61 & 39 & 0.77 & 94 & 1.89 \\
\hline \multirow[t]{4}{*}{ RJ-3 } & Нар & 340 & 222 & 0.65 & 605 & 1.78 & 331 & 0.97 & 294 & 0.86 \\
\hline & $\mathrm{He} 1$ & 315 & 204 & 0.65 & 718 & 2.28 & 363 & 1.15 & 355 & 1.13 \\
\hline & $\mathrm{He} 2$ & 332 & 214 & 0.64 & 750 & 2.26 & 433 & 1.30 & 308 & 0.93 \\
\hline & $\mathrm{Hi}$ & 289 & 226 & 0.78 & 684 & 2.37 & 407 & 1.41 & 397 & 1.38 \\
\hline \multirow[t]{3}{*}{ RJ-4 } & Hap 1 & 92 & 65 & 0.71 & 186 & 2.03 & 82 & 0.89 & 130 & 1.42 \\
\hline & Hap2 & 100 & 55 & 0.55 & 179 & 1.80 & 60 & 0.60 & 107 & 1.08 \\
\hline & $\mathrm{Cg} 1$ & 70 & 31 & 0.44 & 121 & 1.74 & 36 & 0.51 & 89 & 1.27 \\
\hline \multirow[t]{3}{*}{ RS-3 } & $\mathrm{He}$ & 158 & 127 & 0.80 & 450 & 2.84 & 237 & 1.49 & 290 & 1.83 \\
\hline & Ha 1 & 110 & 84 & 0.76 & 255 & 2.31 & 115 & 1.04 & 144 & 1.30 \\
\hline & Ha2 & 69 & 57 & 0.82 & 182 & 2.62 & 39 & 0.57 & 102 & 1.47 \\
\hline \multirow[t]{3}{*}{ RS-4 } & Hpj & 426 & 238 & 0.56 & 763 & 1.79 & 348 & 0.82 & 293 & 0.69 \\
\hline & Hdj & 482 & 220 & 0.46 & 678 & 1.41 & 350 & 0.72 & 476 & 0.99 \\
\hline & Hej & 490 & 198 & 0.40 & 869 & 1.77 & 419 & 0.86 & 506 & 1.03 \\
\hline \multirow[t]{2}{*}{ RS-5 } & Hapj & 359 & 238 & 0.66 & 654 & 1.82 & 331 & 0.92 & 441 & 1.23 \\
\hline & Haj & 292 & 210 & 0.72 & 488 & 1.68 & 242 & 0.83 & 189 & 0.65 \\
\hline \multirow[t]{2}{*}{$\mathrm{SC}-2$} & Hej1 & 460 & 227 & 0.49 & 865 & 1.88 & 353 & 0.77 & 421 & 0.92 \\
\hline & Hej2 & 528 & 222 & 0.42 & 940 & 1.78 & 395 & 0.75 & 538 & 1.02 \\
\hline SP-1 & Hp1 & 207 & 164 & 0.79 & 391 & 1.89 & 235 & 1.13 & 368 & 1.77 \\
\hline & Нp2 & 144 & 112 & 0.78 & 313 & 2.17 & 140 & 0.97 & 313 & 2.10 \\
\hline
\end{tabular}

${ }^{\S} \mathrm{C}-\mathrm{CHN}$, Perkin Elmer 2400 CHNS analyzer; C-Emb, Embrapa (C-Embrapa); OM-Muffle, muffle furnace; C-W \& B md, modified Walkley \& Black, and C-Y \& B, Yeomans \& Bremner. 
Table 3 - Regression analyses coefficients for the carbon and organic matter determinations.

\begin{tabular}{|c|c|c|c|c|c|c|c|c|c|}
\hline \multirow[b]{2}{*}{$\mathrm{Y}$} & \multirow[b]{2}{*}{$\mathrm{X}$} & \multirow[b]{2}{*}{$\mathrm{r}^{2}$} & \multicolumn{4}{|c|}{ Intercept $t^{\S}$} & \multicolumn{3}{|c|}{ Angular coefficient } \\
\hline & & & Min. & Average & Max. & $P$ & Min. & Average & Max. \\
\hline OM-muffle & $\mathrm{C}-\mathrm{CHN}$ & 0.93 & - & - & - & ns & 1.79 & 1.86 & 1.93 \\
\hline OM-muffle & $\mathrm{C}-\mathrm{CHN}$ & 0.94 & 28.6 & 63.5 & 98.3 & 0.1 & 1.56 & 1.68 & 1.80 \\
\hline OM-muffle & $\mathrm{C}-\mathrm{W} \& \mathrm{~B} \mathrm{md}$ & 0.89 & - & - & - & ns & 2.00 & 2.10 & 2.19 \\
\hline OM-muffle & C-Embrapa & 0.88 & - & - & - & ns & 2.78 & 2.98 & 3.18 \\
\hline OM-muffle & $C-Y \& B$ & 0.84 & - & - & - & ns & 1.62 & 1.75 & 1.88 \\
\hline OM-muffle & $\mathrm{C}-\mathrm{Y} \& \mathrm{~B} \mathrm{md}$ & 0.84 & - & - & - & ns & 1.64 & 1.77 & 1.90 \\
\hline C-Embrapa & C-CHN & 0.77 & 18.2 & 40.2 & 63.4 & 0.1 & 0.41 & 0.48 & 0.55 \\
\hline C-Embrapa & $\mathrm{C}-\mathrm{W} \& \mathrm{~B} \mathrm{md}$ & 0.87 & 8.9 & 33.4 & 57.9 & 0.8 & 0.42 & 0.50 & 0.59 \\
\hline C-Embrapa & $C-Y \& B$ & 0.82 & - & - & - & ns & 0.53 & 0.57 & 0.62 \\
\hline C-Embrapa & $\mathrm{C}-\mathrm{Y} \& \mathrm{~B} \mathrm{md}$ & 0.82 & - & - & - & ns & 0.53 & 0.58 & 0.62 \\
\hline $\mathrm{C}-\mathrm{W} \& \mathrm{~B}$ md & $\mathrm{C}-\mathrm{CHN}$ & 0.86 & 4.1 & 30.6 & 57.2 & 2.5 & 0.69 & 0.78 & 0.87 \\
\hline $\mathrm{C}-\mathrm{W} \& \mathrm{~B}$ md & $C-Y \& B$ & 0.85 & - & - & - & ns & 0.86 & 0.92 & 0.99 \\
\hline $\mathrm{C}-\mathrm{W} \& \mathrm{~B} \mathrm{md}$ & $\mathrm{C}-\mathrm{Y} \& \mathrm{~B} \mathrm{md}$ & 0.84 & - & - & - & ns & 0.86 & 0.93 & 1.00 \\
\hline$C-Y \& B$ & $\mathrm{C}-\mathrm{CHN}$ & 0.73 & 45.9 & 84.8 & 123.8 & 0.1 & 0.63 & 0.76 & 0.89 \\
\hline $\mathrm{C}-\mathrm{Y} \& \mathrm{~B} \mathrm{md}$ & C-CHN & 0.73 & 65.9 & 102.1 & 138.3 & 0.1 & 0.58 & 0.70 & 0.82 \\
\hline $\mathrm{C}-\mathrm{Y} \& \mathrm{~B} \mathrm{md}$ & C-CHN & 0.79 & - & - & - & ns & 0.91 & 0.96 & 1.02 \\
\hline
\end{tabular}

Intercept = linear coefficient; C-CHN, Perkin Elmer 2400 CHNS analyzer; C-Embrapa, Embrapa (C-Embrapa); OM-Muffle, muffle furnace; C-W \& B md, modified Walkley \& Black; C-Y \& B, Yeomans \& Bremner; and C-Y \& B md, modified Yeomans \& Bremner

sented in Table 2. Results show higher variability of factors in samples with lower carbon content. The comparison between data from different methods is presented in Figure 1. The dispersion diagrams indicate varying degree of correlation between the procedures.

The muffle furnace (OM-Muffle) method, which measures total organic matter, presented angular coefficient of the linear equation greater than one. The carbon correction factor (f-) for organic matter varied from 1.79 to 1.93 , with an average 1.86 . This value was estimated by regression for the intercept equal to zero (Table 3). When the intercept was different from zero, the angular coefficient ranged from 1.56 to 1.80 , within the confidence interval.

The values for the correction factor $\mathrm{C}-\mathrm{OM}$ through muffle furnace $\left(600^{\circ} \mathrm{C}\right)$ are close to the value of 1.724 adopted by EMBRAPA (1999), and these values are also in agreement with others from literature. An error of the muffle furnace method comes from the presence of calcium or magnesium carbonates or charcoal in the soil sample, although, according to Kerven et al. (2000), the error caused by carbonates may be eliminated by previous treatment with acid. However, an important advantage of the muffle furnace method in relation to others is the operation easiness, what is relevant in routine analyses for soil surveys and other applications.

The Embrapa method (C-Embrapa) is very effective for soil samples up to $20 \mathrm{~g} \mathrm{~kg}^{-1}$ of organic car- bon (EMBRAPA, 1997). However, for histic horizons, a smaller amount of sample must be taken and several additions of dichromate are required, what makes operation difficult, also increasing the analysis error. For obtaining satisfactory results, the experience of the analyst is relevant in the performance of the method, to avoid underestimating the organic carbon content.

Higher data dispersion was observed in the CEmbrapa method (Figure 1) for C-CHN above $400 \mathrm{~g}$ $\mathrm{kg}^{-1}$, showing a lower efficiency of this analysis within this range. The determination coefficient (Table 3) was not high for this method, especially through the deviations in the range above $400 \mathrm{~g}$ of C-CHN. An intercept above zero and angular coefficient of the linear equation coefficient ranging from 0.41 to 0.55 was observed. These results demonstrate that the C-Embrapa method had a low oxidation capacity, especially for the high soil organic matter samples. Therefore, soil materials that could be defined as organic for soil taxonomy purposes (FAO, 1998; USDA, 1999) if quantified the organic carbon by other method, would be classified as mineral soil materials when measured by the Embrapa method.

A comparison between organic carbon content, measured through C-Embrapa and C-CHN methods, from 19 highly weathered Brazilian soils, resulted in a linear regression (Pérez et al., 2001), demonstrating no significant differences between values of organic carbon obtained through different methods. Results 
obtained in this study showed low but significant correlation between C-Embrapa and OM-Muffle, and C$\mathrm{W} \& \mathrm{~B}$ md and C-Embrapa (Figure 1); regression coefficients were 0.489 and 0.499 , respectively. The discrepancy of results according to methods emphasizes the need for distinguishing mineral soil materials from soils with high organic matter content, such as the Histosols, when analyzing organic carbon.

The carbon content determined through modified Walkley-Black (C-W \& B md) (Tedesco et al., 1995), and Yeomans \& Bremner (1988) (C-Y \& B) methods showed similarities, when compared to each other and to the C-Embrapa method, but with linear coefficients higher and closer to one (Table 3). The principle involved in all three methods is the oxidation of organic matter by dichromate in acid medium. Therefore, although there was a good correlation with the $\mathrm{C}-\mathrm{CHN}$, the organic carbon oxidation efficiency is low for most soil samples, requiring the use of adjustment factors. The C-CHN method oxidizes and quantifies total carbon, including carbon in charcoal and carbonates, which are common in many of the Histosols and soils with histic horizons, and the dichromate-combustion method, only oxidizes part of the soil carbon. As a result, the methods may over or underestimate the amount of soil organic carbon (Kerven et al., 2000). Correction factors may be needed when these methods are used for soils with high organic carbon, mainly in coastal areas, where the levels of carbonates are high.

The C-Y \& B method was modified in the titration process, exchanging N-phenylanthranilic acid by the indicator diphenylamine (C-Y \& B md). The regression analysis showed that the modification did not affect the organic carbon determination; therefore, the methods are correspondent. The advantage of the C$\mathrm{Y} \& \mathrm{~B}$ md method is that, in the absence of $\mathrm{N}$ phenylanthranilic, the indicator diphenylamine may be used as well.

Table 3 also presents the result of regression analysis. The dependent variable is OM-muffle furnace and the independent variable is $\mathrm{C}-\mathrm{W} \& \mathrm{~B} \mathrm{md}$. Based on results of $\mathrm{C}-\mathrm{W} \& \mathrm{~B}$ md, the OM-muffle may be estimated from $\mathrm{C}-\mathrm{W} \& \mathrm{~B} \mathrm{md}$, by applying a factor that ranges from 2.00 to 2.19 with $95 \%$ of probability. The factor 2.10 , the average value, is suggested to convert results obtained by these methods.

The C-W \& B md method for organic carbon and the OM-muffle for organic matter determination seem to be the most suitable methods, for soil samples with high organic matter content. They have as main advantage operational easiness and they showed high determination coefficient values, when compared with the C-CHN method, used in this study to quantify total carbon in the soil.

\section{REFERENCES}

ALLISON, L.E. Organic carbon. In: BLACK, C.A.; EVANS, D.D.; ENSMINGER, L.E.; WHITE, J.L.; CLARK, F.E. Methods of soil analysis. Madison: ASA, 1965. v.2, p.1367-1379. (Agronomy, 9).

EMPRESA BRASILEIRA DE PESQUISA AGROPECUÁRIA. Centro Nacional de Pesquisa de Solos. Manual de métodos de análises de solos. 2.ed. Rio de Janeiro: EMBRAPA, CNPS, 1997. 212p.

EMPRESA BRASILEIRA DE PESQUISA AGROPECUÁRIA. Centro Nacional de Pesquisa de Solos. Sistema brasileiro de classificação de solos. Brasília: Embrapa Produção da Informação, 1999. 412p.

FAO. World reference base for soil resources. Rome: FAO; ISSS; ISRIC, 1998. 88p. (World Soil Resources Reports, 84).

GOLDIN, A. Reassessing the use of loss-on-ignition for estimating organic matter content in noncalcareous soils. Communications in Soil Science and Plant Analysis, v. 18, p.1111-1116, 1987.

KERVEN, G.L.; MENZIES, N.W.; GEYER, M.D. Soil carbon determination by high temperature combustion - a comparison with dichromate oxidation procedures and the influence of charcoal and carbonate carbon on the measured value. Communications in Soil Science and Plant Analyses, v.31, p.1935-1939, 2000.

MILLER, J.C.; MILLER, J.N. Statistics for analytical chemistry. 3.ed. New York: Ellis Horwood, 1993. 256p.

PÉREZ, D.V.; ALCÂNTARA, S.; ARRUDA, J.; MENEGHELLI, N.A Comparing two methods for soil carbon and nitrogen determination using selected Brazilian soils. Communications in Soil Science and Plant Analysis, v.32, p.295-309, 2001.

TEDESCO, M.J.; GIANELLO, C.; BISSANI, C.A.; VOLKWEISS, S.J. Análises de solo, plantas e outros materiais. 2.ed. Porto Alegre: UFRGS, Depto de Solos, 1995. 174p.

UNITED STATES. Department of Agriculture. Natural Resources Conservation Service. Soil survey laboratory methods manual. Version 3.0. Washington: National Soil Survey Center, 1996. 440p. (Soil Survey Investigations Report, 42).

UNITED STATES. Department of Agriculture. Natural Resources Conservation Service. Soil Survey Staff. Soil taxonomy: a basic system of soil classification for making and interpreting soil surveys. 2.ed. Washington, 1999. 169p. (Agriculture Handbook, 436).

WALKLEY, A. An examination of methods for determining organic carbon and nitrogen in soils. Journal of Agricultural Science, v.25, p.598-609, 1935.

WALKLEY, A.; BLACK, I.A. An examination of the Degtjareff method for determining soil organic matter, and proposed modification of the chromic acid titration method. Soil Science, v.37, p.29-38, 1934.

WALKLEY, A. A critical examination of a rapid method for determination, organic carbon in soils: effects of variations in digestion conditious and organic soils constituints. Soil Science, Baltimore, v.63, p.251-263, 1946.

YEOMANS, J.C.; BREMNER, J.M. A rapid and precise method for routine determination of organic carbon in soil. Communications in Soil Science and Plant Analysis, v.19, p.1467-1476, 1988. $\overline{\text { Received June 22, }} 2005$

Accepted December 28, 2005 